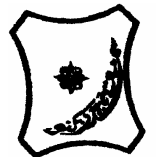

Bayero Journal of Pure and Applied Sciences, 6(1): $169-173$

Received: November 2012

Accepted: February 2013

ISSN 2006 - 6996

\title{
EFFECTS OF EXTRACTION METHOD ON THE PHYSICOCHEMICAL AND MYCOLOGICAL QUALITIES OF CANARIUM SCHWEINFURTHII FRUIT OIL
}

\author{
${ }^{1 *}$ Nyam, M. A. ${ }^{1}$ Wonang, D. L. ${ }^{1}$ Ogbonna, C.I.C. ${ }^{2}$ Ochekpe, N. and ${ }^{3}$ Dapiya, H. S \\ ${ }^{1}$ Department of Plant Science and Technology, ${ }^{2}$ Department of Pharmaceutical Sciences, \\ ${ }^{3}$ Department of Microbiology, University of Jos, Plateau State, Nigeria \\ *Correspondence author; hycinthd@yahoo.com
}

\begin{abstract}
The effects of improved method of extraction on the physicochemical, mycological and stability of crude Canarium Schweinfurthii fruit oil were studied. The extracted oils were then stored at $25 \pm 5^{\circ} \mathrm{C}$ for 24 months with samples analyzed at 6months interval for; pH, saponification value, acid value, peroxide value and iodine number. Similarly, enumeration and identification of fungi species was determined using standard mycological procedures. The results showed that crude Canarium Schweinfurthii fruit oil obtained by the improved method of extraction had better quality and stability parameters than the traditional method extracted oil. At 24months the oil quality values of; pH $5.20-6.61$, Acid value $0.53-1.02(\mathrm{mg}$ of $\mathrm{KOH} / \mathrm{g}$ ), saponification value 151.30 $179.52(\mathrm{mg}$ of $\mathrm{OH} / \mathrm{g})$, peroxide value $0.031-1.500\left(\mathrm{meq} \mathrm{O}_{2} / \mathrm{K}_{\mathrm{g}}\right.$ ) and iodine value $85.02-101.60$ $\left(g I_{2} / 100 g\right)$. Comparatively, no significant difference $(P>0.05)$ was observed for $p H$ and saponification values for the extracted oils, with values of $6.60,178.60(\mathrm{mg}$ of $\mathrm{OH} / \mathrm{g})$ and 6.62 , 178.52( $\mathrm{mg}$ of $\mathrm{OH} / \mathrm{g}$ ) for traditional and improved extraction methods respectively. During storage the oils showed average fungal counts of 00.00 to $1.72 \times 10^{5}$ and 00.00 to $8.00 \times 10^{4} \mathrm{CFU} / \mathrm{ml}$ oil at 0 and 24 month for traditional and improved methods extracted oils respectively. Predominant fungal species; Aspergillus niger, Rhizopus stolonifer, Sacccaromyces cerevisiae, Mucor spinosus, Penicillium patalun, Fusarium oxysprum and Candida scotti were found associated with the stored canarium oil. Generally, Mucor spinosus (80.00\%), Aspergillus niger (80.00\%) and Penicillium patalum (80.00\%) had the highest occurrence in traditional extracted oil. This finding suggests the need for the local processors to reevaluate the full processing method in order to retain better fungal quality and oxidative stability for Canarium schweinfurthii fruit oil.

Keywords: Canarium schweinfurthii, fruit oil, Extraction, Fungal Isolates, Oxidative stability
\end{abstract}

\section{INTRODUCTION}

Canarium schweinfurthii otherwise known as African Canarium or black olive have been extensively utilized by traditional societies for its fruits and oil contents. The plant specie is native to tropical Africa, Southern Asia (Orwa et al., 2009) and in Nigeria, the climate and vegetation of Plateau state favours its growth and fruits production throughout the year. $C$. scheweinfirthii plant has been widely domesticated predominantly in rocky and flat lands of Wokkos, Shere, Fobor, Vom, Toff and Mangu areas of Plateau state.

Despite the growing demand for canarium fruit oil, there seems to be little attention placed on application of improved method of extraction particularly in the developing countries. In Nigeria, the traditional methods of extraction are still widespread among most communities where the plant is dominant. In most local communities, the fruit oil extraction method is usually a manual process involving preliminary processing and hand pressing comparatively, to the modern classic pressing and the continuous centrifugal systems (Boskou, 1996; Kiritsakis and Christie, 2000).

Fermentation is still the common method in practice for $C$. schwenfuthii oil extraction among communities in Plateau state, although details of the procedures vary from one locality to another. Basically the process usually involve; pre warming, half drying, mashing, fermentation, decanting and finally sieving. Importantly, fermentation method still finds application due to the believe that it enhances the oil flavours, also the fruit emulsion is condition such that it ease separation of oil from carbohydrate, proteins and water phase (Rahayu et al., 2008). Despite its long application, the traditional oil extraction methods always lack the aseptic procedures and could result in microbial contamination that may infer quality deterioration of vegetable oils (Ekwenye, 2006). Work by Soeka et al. (2008) reported low quality vegetable oil traditionally extracted due to its high moisture and free fatty acid contents.

Therefore, for small oil producers and developing community-based agro-allied activities to be viable and sustainable, it is necessary for the adoption of simple improved extraction methods. This will no doubt develop the capacity of local artisans and add to their production outputs. Due to these, concern on improving the extraction process, monitoring its effects on the quality and growth of spoilage fungi in the stored $C$. schweinfurthrii fruit oil is generated. 


\section{MATERIALS AND METHODS Sample Collection}

Ripe black C. schweinfirthii fruits were purchased from Fobor and Toff villages in Plateau state. A total of $10 \mathrm{~kg}$ of the fruits were each collected from two trees with history of high oil production. The ripe fruits were harvested by hand plucking on tree tops at morning hours when temperatures are low. The fruits were then transported to the laboratory in cleaned polythene bags for analysis.

\section{Sample Preparation}

For the improved oil extraction, the harvested fruits were first sorted to remove foreign materials, unripe and infected fruits. The fruits were then weighed and washed with $30 \%$ table salt solution for 15 minutes and rinsed extensively with sterile tap water.

\section{Improved Extraction of Fruit oil}

The fruit oil was extracted following the traditional procedures with modifications as previously adopted (Agu et al., 2008). The cleaned fruits were completely steeped in $18-20^{\circ} \mathrm{C}$ water for 15 minutes to soften the fruit mesocarp and then sundried for 3 days in cleaned trays. The dried fruits were further washed with $30 \%$ table salt solution and rinsed in sterile tap water. Subsequently, the fruits obtained were mashed into paste using cleaned wooden pestle and mortar. Then the paste formed was packed in a clean plastic bucket and mixed with 20 liters boiled water $\left(100^{\circ} \mathrm{C}\right)$ and fermented at room temperature $\left(28+2^{\circ} \mathrm{C}\right)$ for 48 hours. The foam on top layer and oil formed were skimmed and scooped out respectively using sterile wooden spoon. Further separation of the oil was then carried out by sieving using cheese cloths.

\section{Storage study}

A total of $200 \mathrm{~cm}^{3}$ of C. Schweinfuthii fruit oil was dispensed in sterile plastic bottles and stored at room temperature $\left(28 \pm 2^{\circ} \mathrm{C}\right)$. The oils extracted using traditional and improved extraction methods were sampled at 0, 6, 12, 18 and 24 months intervals for physicochemical and fungal analysis. The study was designed so that samples were measured in triplicates for the five storage periods.

\section{Physicochemical Analysis}

Physicochemical analysis of the fruit oil extracted was carried out according to the standard methods of AOAC, (1990). The parameters analysed include; $\mathrm{pH}$, saponification value, acid value, peroxide value and iodine number

\section{Microbiological analysis}

Enumeration and identification of fungi species associated with the fruit oil was carried out on Sabouraud's Dextrose Agar (Oxoid) fortified with $50 \mathrm{mg} / \mathrm{ml}$ streptomycin following standard procedures adopted by Negedu et al. (2010). The inoculated plates were incubated at $25^{\circ} \mathrm{C}$ for 5 days and colonies formed were counted and sub cultured until pure isolates were obtained.

\section{Statistical analysis}

Analysis of samples was carried out in triplicate and data obtained were expressed as means \pm standard deviation (SD). Differences between means were analysed by analysis of variance (one way ANOVA) using StatPlus 2008 (Analystsoft Inc) software. Statistical significance was measured at $p<0.05$.

\section{RESULTS}

The effects of extraction methods on the stability of $C$. schweinfurthii fruit oil is presented in Table 1 . The result showed that at 24 months of storage, the oil extracted varied in $\mathrm{pH} 5.20-6.61$, Acid value $0.53-$ $1.02(\mathrm{mgKOH} / \mathrm{g})$, saponification value $151.30-179.52$ $(\mathrm{mgOH} / \mathrm{g})$, peroxide value $0.031-1.500\left(\mathrm{meq0}_{2} / \mathrm{K}_{\mathrm{g}}\right)$ and iodine value $85.02-101.60 \quad\left(\mathrm{gI}_{2} / 100 \mathrm{~g}\right)$. Comparatively, no significant difference ( $P>0.05$ ) was observed for $\mathrm{pH}$ and saponification values of the extracted oils, with values of $6.60,178.60$ and 6.62 , 178.52 for traditional and improved extraction methods respectively. Generally, the result showed that while $\mathrm{pH}$, SV and IV of the oils decreases AV and PV increases with storage period.

Mycological quality of stored African olive oil extracted using traditional and improved processes is presented in Table 2. Generally, there was no noticeable fungal growth on freshly extracted oils, however on storage increased fungal counts was observed at a significantly $(P<0.05)$ lower rate in the improved extracted oil. On storage however, the mean total fungal count on the oil ranged from 00.00 to 1.72 $\mathrm{x} 10^{5}$ and 00.00 to $8.00 \times 10^{4} \mathrm{CFU} / \mathrm{ml}$ oil at 0 and 24 month storage period for traditional and improved extracted oil respectively was observed.

Predominant fungi species; $A$. niger, $R$ stolonifer, $S$. cerevisiae, M. spinosus, $P$. patalun, F. oxysprum and C. scotti were found associated with stored oil. Occurrence of fungi species in stored C. schweinfurthii fruit oil extracted using traditional and improved methods is presented in Table 3.The result showed that $A$. niger $(80 \%), \quad$ M. spinosus $(80 \%)$ and $P$. patalun( $80 \%)$ are the most predominant fungi species contaminating the stored oil, while F. oxysprum (40\%) was the least occurred.

\section{DISCUSSION}

The study provides a comparative assessment of the mycological and physico chemical quality of $C$. schweinfurthii fruit oil extracted using two methods. Generally the result showed that the improved extraction method impacted a significantly higher quality and stability characteristics to the $C$. schweinfurthii fruit oil.

Similarly, studies on the effect of extractions methods on quality of vegetable oils had reported alteration in chemical composition and oxidative stability of the oil (Hopia, 1993; Vekiari et al., 2002; Dimkpa and Onuegbu, 2010; Tasan et al., 2011). Fundamentally, in this study the obvious variation in the extraction methods centered on the applications of conditions that improved quality of the processes. Studies by Vinha et al. (2005) and Chabiri et al. (2009) had reported sanitary conditions of the processing as a major factor affecting olive oil quality. Also processing steps such as decanting had been reported to be responsible for high acidity in olive oils (Vaz - Freire et al., 2008). Therefore, the application of cleaning, brining and aseptic handling that characterised the improved fermentation method lowered fungi contamination and growth in the oil. 
Table 1: Physicochemical Quality of Stored Canarium schweinfurthii Fruit Oil Extracted Using Traditional and Improved Methods

\begin{tabular}{|c|c|c|c|c|c|c|c|c|c|c|}
\hline \multirow{2}{*}{ Storage period (Months) } & \multicolumn{5}{|c|}{ Traditional method } & \multicolumn{5}{|c|}{ Improved method } \\
\hline & $\mathrm{pH}$ & SV & AV & IV & PV & $\mathrm{pH}$ & SV & AV & IV & PV \\
\hline 0 & $6.60 \pm 0.02$ & $178.60 \pm 2.31$ & $0.60 \pm 0.005$ & $104.80 \pm 0.60$ & $0.93 \pm 0.03$ & $6.63 \pm 0.02$ & $179.52 \pm 2.07$ & $0.35 \pm 0.01$ & $98.40 \pm 1.56$ & $0.03 \pm 0.003$ \\
\hline 6 & $6.56 \pm 0.03$ & $178.03 \pm 1.46$ & $0.58 \pm 0.01$ & $101.60 \pm 0.08$ & $0.89 \pm 0.03$ & $6.60 \pm 0.06$ & $179.31 \pm 3.00$ & $0.50 \pm 0.03$ & $98.20 \pm 2.01$ & $0.04 \pm 0.02$ \\
\hline 12 & $6.02 \pm 0.03$ & $173.04 \pm 2.06$ & $0.65 \pm 0.00$ & $96.06 \pm 0.40$ & $1.01 \pm 0.07$ & $6.51 \pm 0.01$ & $174.01 \pm 3.01$ & $0.56 \pm 0.02$ & $97.50 \pm 0.97$ & $0.50 \pm 0.01$ \\
\hline 18 & $5.80 \pm 0.04$ & $168.00 \pm 1.76$ & $0.75 \pm 0.02$ & $87.80 \pm 0.03$ & $1.21 \pm 0.00$ & $6.05 \pm 0.00$ & $165.40 \pm 0.86$ & $0.71 \pm 0.05$ & $89.30 \pm 1.05$ & $0.61 \pm 0.04$ \\
\hline 24 & $5.20 \pm 0.01$ & $151.30 \pm 2.02$ & $1.02 \pm 0.06$ & $85.02 \pm 2.54$ & $1.50 \pm 0.09$ & $5.80 \pm 0.78$ & $164.00 \pm 2.06$ & $0.93 \pm 0.01$ & $87.60 \pm 2.02$ & $0.83 \pm 0.03$ \\
\hline
\end{tabular}

$\mathrm{SV}=$ Saponification value $(\mathrm{mg} \mathrm{KOH} / \mathrm{g}), \mathrm{AV}=$ Acid value $(\mathrm{mg} \mathrm{KOH} / \mathrm{g}), \mathrm{IV}=$ Iodine number $\left(\mathrm{g} \mathrm{I}_{2} / 100 \mathrm{~g}\right), \mathrm{PV}=$ Peroxide value $\left(\mathrm{meq} \mathrm{O}_{2} / \mathrm{kg}\right)$

\begin{tabular}{|c|c|c|c|c|c|c|c|c|c|c|}
\hline \multirow[t]{2}{*}{$\begin{array}{l}\text { Fungi } \\
\text { Isolates }\end{array}$} & \multicolumn{5}{|c|}{$\begin{array}{l}\text { Traditional method } \\
\text { Storage period(months)/Total fungi counts } \\
\left(\times 10^{4} \mathrm{CFU} / \mathrm{ml}\right)\end{array}$} & \multicolumn{5}{|c|}{$\begin{array}{l}\text { Improved method } \\
\text { Storage period(months) /Total fungi counts } \\
\left(\times 10^{4} \mathrm{CFU} / \mathrm{ml}\right)\end{array}$} \\
\hline & 0 & 6 & 12 & 18 & 24 & $\mathbf{0}$ & 6 & 12 & 18 & 24 \\
\hline A niger & 00.00 & $9.00 \pm 1.20$ & $15.00 \pm 2.00$ & $21.00 \pm 1.20$ & $34.00 \pm 2.60$ & 00.00 & $1.00 \pm 0.10$ & $6.00 \pm 0.20$ & $10.00 \pm 1.00$ & $14.00 \pm 2.20$ \\
\hline R. stolonifer & 00.00 & 00.00 & $3.00 \pm 0.40$ & $7.00 \pm 1.08$ & $11.00 \pm 0.20$ & 00.00 & 00.00 & $4.00 \pm 0.00$ & $6.00 \pm 1.20$ & $9.00 \pm 1.80$ \\
\hline S. cerevisiae & 00.00 & 00.00 & $6.00 \pm 1.00$ & $10.00 \pm 1.40$ & $17.00 \pm 1.00$ & 00.00 & 00.00 & $2.00 \pm 0.40$ & $8.00 \pm 1.60$ & $12.00 \pm 2.60$ \\
\hline M. spinosus & 00.00 & $13.00 \pm 2.00$ & $18.00 \pm 1.80$ & $25.00 \pm 0.60$ & $36.00 \pm 2.00$ & 00.00 & $2.00 \pm 0.60$ & $5.00 \pm 0.20$ & $7.00 \pm 1.00$ & $12.00 \pm 1.20$ \\
\hline P. patalum & 00.00 & $3.00 \pm 0.80$ & $3.00 \pm 0.60$ & $10.00 \pm 2.00$ & $16.00 \pm 1.20$ & 00.00 & 00.00 & $5.00 \pm 0.20$ & $6.00 \pm 2.00$ & $9.00 \pm 0.80$ \\
\hline F. oxysporum & 00.00 & 0.00 & 00.00 & $2.00 \pm 0.20$ & $3.00 \pm 0.60$ & 00.00 & 00.00 & 00.00 & 00.00 & 00.00 \\
\hline C. scotti & 00.00 & 0.00 & $3.00 \pm 0.40$ & $5.00 \pm 0.40$ & $4.00 \pm 1.00$ & 00.00 & 00.00 & 00.00 & 00.00 & 00.00 \\
\hline Average & 00.00 & 3.57 & 6.86 & 11.42 & 17.29 & 0.00 & 0.42 & 3.14 & 5.29 & 8.00 \\
\hline
\end{tabular}

$00.00=$ No growth

Table 3: Occurrence of Fungal species in Stored Canarium schweinfurthii Fruit Oil Extracted Using Traditional and Improved Methods

\begin{tabular}{llll}
\hline $\begin{array}{l}\text { Fungi } \\
\text { Isolates }\end{array}$ & $\begin{array}{l}\text { Occurrence } \\
\text { Extracted Oil } \\
\text { Number (\%) }\end{array}$ & $\begin{array}{c}\text { Traditional } \\
\text { in }\end{array}$ & $\begin{array}{l}\text { Occurrence } \\
\text { Extracted Oil } \\
\text { Number (\%) }\end{array}$ \\
\hline Apergillus niger & $4(80.00)$ & $4(80.00)$ \\
Rhizopus stolonifer & $3(60.00)$ & $3(60.00)$ \\
Saccharomyces cerevisiae & $3(60.00)$ & $3(60.00)$ \\
Mucor spinosus & $4(80.00)$ & $4(80.00)$ \\
Penicillium patalum & $4(80.00)$ & $3(60.00)$ \\
Fusarium oxysporum & $2(40.00)$ & 00.00 \\
Candida scotti & $3(60.00)$ & 00.00 \\
\hline
\end{tabular}


This agrees with the finding of Dimkpa, and Onuegbu, (2010) that cleaning and brine disinfection protocols had no significant effect on the total oil contents of the copra, total free fatty acid and iodine value but significantly affected the severity of infection of the mycoflora. Similarly, Onuegbu and Ihuanne (1994) reported reduction in growth of $A$. niger, Penicillium spp. and Cladosporium sp., in palm oil using common salt.

From this study, no visible fungal growth was observed in the freshly extracted oils, however surviving fungi spores manifested with incubation period and favorable conditions. This could be attributed to the destruction of vegetative fungi cells during the brining and boiling treatments. Fungal isolates had been reported to play a significant role in the deterioration of vegetable oil (Negedu et al., 2010) and hence reduced its economic value and possible industrial applications. Of upmost concern is that the presence of these fungi particularly when stored for excessive period of time pose potential health hazard to the consumers of the canarium fruit oil.

One of the major quality determinants of vegetable oils is its peroxide value which measures progress of oxidation (Gulla and Waghray, 2012). Apart from the fact that this study provides information on the degree of oxidation of traditionally extracted canarium fruit oils comparatively however, lower mean peroxide

\section{REFERENCES}

Agu, H.O., Ukonze, J.A. and Uchola, N.O. (2008): Quality characteristics of crude and refined Atili oils. Pakistan Journal of Nutrition, 7 (1): 27-30.

AOAC (1990): Official Methods of Analysis of the Association of Official Analytical Chemists 15th ed, Association of Official Analytical Chemists Washington DC.

Boskou, D. (1996): Storage and packing. In: Boskou D. Olive Oil: Chemistry and Technology. AOCS Press, Champaign, Illinois. pp. 91-95

Chabiri, S.A. , Hati, S.S. , Dimari, G.A. and Ogugbuaja, V.O. (2009): Comparative Quality Assessment of Branded and Unbranded Edible Vegetable Oils in Nigeria. The Pacific Journal of Science and Technology, 10 (2): 927-934

Dimkpa, S.O.N. and Onuegbu, B.A. (2010): Mycoflora of copra and effect of brining on some properties of copra in Nigeria. Agric. Biol. J. N. Am., 1(3): 391-394

Ekwenye, U. N (2006): Chemical characteristics of palm oil biodeterioration. Biokemistri., 18(2):141-149.

Hopia, A. (1993): Analysis of high molecular weight autooxidation products using high performance size exclusion chromatography: 11 changes during processing. Lebensm, wiss u Techno., 26,568-571.

Gulla, S. and Waghray,K. (2012): Blending of oils: A case study on storage stability and sensory values was observed in the improved extracted oil. Obviously, high fungal growth associated with the traditionally extracted oil could be responsible for the built up of peroxide values. Accordingly, the predominant fungi species isolated had been incriminated in continuous increase in oxidation values of mould infected oils (Ilori et al. 2007; Negedu et al., 2010). Relatively, the range of peroxide values (meg/kg) reported by Agu et al. (2008) for both long and short varieties of "atili" oil (0.76 - 1.04 and 0.88 1.39 respectively) was higher than values obtained in this study. The decrease in the peroxide value after refining may be due to the superiority of fermentation extraction over warm pressing extraction method adopted. Similarly after 24 months of storage, the peroxide values obtained were lower than the $42-$ $47 \mathrm{meq} / \mathrm{kg}$ at which vegetable oils become unfit for human consumption and 20 (meq/ $\mathrm{kg}$ ) olive oils market recommended limit (IOC, 2007). This study has reaffirmed that the improved method of handling of $C$. scheweinfurthii fruits during extraction could be adopted to provide oil with quality and improved storage stability.

\section{CONCLUSION}

Based on the results of this study, improved method adopted for the extraction of $C$. scheweinfurthii fruit oil showed gross reduction in fungal contamination as well as enhanced higher oil quality on storage.

characteristics of a ready to eat extruded snack .Journal of Dietetics and Food Science, 2(1):1-12

Ilori, R.M., Onifide, A.K. and Adetuyi, F.C. (2007): Microbiological and nutritional quality of soya oil. Journal of Food Techno., 5(2).187-190.

IOC (2007): Sensory analysis of olive oil. Method for the organoleptic assessment of virgin olive oil. COI/T.20/Doc. 15/ Rev. 2.

Kiritsakis, A. and Christie, W.W. (2000): Analysis of edible oils. In: Harwood, J. and Aparicio, R.. (Eds.) Handbook of Olive Oil: Analysis and Properties, Aspen Publishers, Inc.Gaithersburg, Maryland. pp. 129-158,

Negadu,A. Dapiya, H.S., Wartu, J.R. and Migap, H.H. (2010): Biodeterioration of soyaben oil by mesophilic moulds. Biol and Env Scien J. of the Tropics, 7(3):113-118.

Onuegbu, B.A and Ihuanne, H.A. (1994): Effect of Common salt on stored oil of oil palm Elaeis guineensis. Indian J. Agric. Sci. 64(9): 647649.

Orwa, C., Mutua, A., Kindt, R., Tamnadass, R. and Anthony, S. (2009): Agroforestree Database: A tree reference and selection guide version 4.0.http://www.worldagroforestry.org/treedb 2/AFTPDFS/Bauhinia_rufescens.pdf.v

Rahayu, R.D., Sulistyo, J. and Dinoto, A. (2008): Enzymatic properties of microbial solid starters on coconut oil recovery. Proceeding of the International Seminar on Chemistry. $679-686$ 
Soeka, Y.S., Sulistyo, J. and Naiola, D. E. (2008): Analisis biokimia minyak kelapa hasil ekstraksi secara fermentasi. Biodiversitas, 9 (2): 91-95.

Tasan, M., Gecgel, U. and Demirci, M. (2011): Effects of storage and industrial oilseed extraction methods on the quality and stability characteristics of crude sunflower oil (Helianthus annuus L.). grasas y aceites, 62 (4): 389-398,

Vaz Freire, L., Gouveia, J.M. and Costa-Freitas, A.M. (2008): Analytical characteristics of olive oils produced by two different extraction techniques, in the Portuguese olive variety Galega Vulgar. Grasas Aceites, 59:260-266.
Vekiari,S.A., Papadopoulou, P. and Koutsaftakis, A. (2002): Comparison of different olive oil extraction systems and the effect of storage conditions on the quality of the virgin olive oil. Grasas Y. Aceites 53(3), $324-329$.

Vinha, A.F., Ferreres, F., Silva, B.M., Valentao, P., Gonçalves, A. and Pereira JA (2005): Phenolic profiles of Portuguese olive fruits (Olea europaea L): Influences of cultivar and geographical origin. Food Chem, 89: 561-5 